\title{
Antimicrobial Potential of Medicaments Used in Healing Process in Dogs' Teeth with Apical Periodontitis
}

\author{
Carlos ESTRELA ${ }^{1}$ \\ Roberto HOLLAND ${ }^{2}$ \\ Pedro Felício Estrada BERNABÉ2 \\ Valdir de SOUZA ${ }^{2}$ \\ Cyntia R.A. ESTRELA ${ }^{1}$ \\ ${ }^{1}$ Faculty of Dentistry, Federal University of Goiás, Goiânia, GO, Brazil \\ ${ }^{2}$ Discipline of Endodontics, Department of Restorative Dentistry, Faculty of Dentistry of Araçatuba, UNESP, \\ Araçatuba, SP, Brazil
}

\begin{abstract}
The objective of this study was to evaluate the influence of irrigants on the antimicrobial potential of calcium hydroxide paste in dogs' teeth with apical periodontitis. Forty-eight premolar teeth of adult mongrel dogs had their root canals opened to the oral environment for 6 months. The root canals were prepared and treated with different irrigating solutions and intracanal medicaments, according to the following groups: 1) $2.5 \%$ sodium hypochlorite $(\mathrm{NaOCl})+$ calcium hydroxide paste $(\mathrm{CHP}) ; 2) 2 \%$ chlorhexidine $(\mathrm{CHX})+\mathrm{CHP}$; 3 ) vinegar + CHP; 4) vinegar + vinegar. In group 4, both the irrigating solution and intracanal medicament were vinegar, which was renewed every 7 days. Each sample was collected by using two paper points maintained in position for 1 min, and individually transported and immersed in $7 \mathrm{~mL}$ of Letheen broth (LB), followed by incubation at $37^{\circ} \mathrm{C}$ for $48 \mathrm{~h}$. Microbial growth was analyzed by two methods: turbidity of the culture medium and subculture on a specific nutrient broth (brain heart infusion). After 21 days, all experimental groups had microbial growth, however, in different percentages: group $1-30 \%$; group 2 - 30\%; group 3 - 40\%; group 4 - $60 \%$. All materials tested had antimicrobial potential; however, the influence of calcium hydroxide paste on the control of microorganisms must be remembered.
\end{abstract}

Key Words: calcium hydroxide, sodium hypochlorite, chlorhexidine, vinegar, antimicrobial activity.

\section{INTRODUCTION}

The importance of microorganisms in the root canal has been the object of discussion for many years. Microbial control in endodontic infections allows for a high success rate in endodontic treatment. In clinical situations, endodontic treatment aims to eliminate microorganisms from the root canal system by means of the association of procedures, i.e., biomechanical preparation, irrigation with different solutions and the use of intracanal dressings.

The effectiveness of intracanal dressings on the success rate in teeth with apical periodontitis has been discussed (1-8). Byström et al. (2) recovered bacteria from one of 35 root canals treated by calcium hydroxide paste (CHP) after 30 days and suggested that the endodontic treatment of infected root canals can be completed in two sessions when CHP is used as an intracanal dressing. Katebzadeh et al. (3), analyzing histological periapical repair after obturation of infected root canals in dogs, reported better results when root canal treatment was done in multiple sessions rather than in one session. Trope et al. (4) evaluated the radiographic healing of teeth with apical periodontitis treated in one or in two visits and with or without CHP as an intracanal dressing. The teeth that were left empty between appointments had clearly poorer healing results. The additional disinfecting action of CHP before obturation 
resulted in a $10 \%$ increase in healing rates. Holland et al. (5) studied the healing process in dogs' teeth with apical periodontitis after root canal treatment in either one or two sessions (with CHP for 7 and 14 days). After 6 months, the histomorphologic analysis showed that the experimental groups were ranked from best to worst in the following sequence: 1) CHP - 14 days; 2) CHP 7 days; 3 ) one session. It was concluded that the use of an intersession calcium hydroxide dressing yields better results than treatment in one session.

Several well-conducted studies (5-8) showed excellent results when using CHP as an intracanal dressing in teeth with periapical infection, highlighting two important properties of calcium hydroxide: the expressive antimicrobial effectiveness and the ability to stimulate mineralization.

Therefore, considering that in one-session root canal treatment, microorganisms reportedly persist in spite of the therapy (2-7), it is worth evaluating other therapeutic options for effective and rapid elimination of microorganisms. Endodontic irrigants can positively influence microbial control.

Holland et al. (9) studied the influence of irrigation and intracanal dressing on the healing process of dogs' teeth with apical periodontitis and found that the use of antibacterial intracanal dressing in teeth with apical delta and apical periodontitis provide better results than the use of no dressing. In addition, the authors reported that the treatment results were not influenced by the type of irrigant used (either saline or Dakin's solution). Other chemical substances need to be investigated, especially comparing those with different antimicrobial mechanisms of action, concentrations and immunologic characteristics.

$\mathrm{NaOCl}$ and chlorhexidine (CHX) are antimicrobial agents often used in the treatment of both endodontic and periodontal infections. However, these substances have distinct characteristics and the literature has shown different results when their antimicrobial effect is compared $(10,11)$. These differences may possibly be attributed to the use of different experimental methods, biological indicators, concentrations or periods of analysis.

Vinegar has been used as an antiseptic agent for many years (12-14) and has been indicated for the treatment of infected wounds, as well as in different health areas (12). However, the effect of vinegar on the endodontic microbiota has not yet been investigated. It is important to consider the possible antimicrobial characteristics associated with its action on tissue healing.

Therefore, the purpose of this study was to evaluate the influence of $2.5 \% \mathrm{NaOCl}, 2 \% \mathrm{CHX}$ and vinegar, used as intracanal medicaments, on the antimicrobial potential of CHP in dogs' teeth with apical periodontitis.

\section{MATERIAL AND METHODS}

Forty-eight roots of premolars of adult mongrel dogs were used in this study. After general anesthesia with Zoletil ${ }^{\circledR}$ 50, the teeth were submitted to crown opening and pulpectomy up to the apical delta. The root canals remained open and exposed to the oral environment for 6 months to induce periapical lesion. After radiographic control and placement of a rubber dam, the teeth were submitted to different modalities of treatment, making up experimental groups with 10 roots each. As control, 8 roots were selected and received no further treatment. The rubber dam was decontaminated with $2.5 \%$ sodium hypochlorite $(\mathrm{NaOCl})$ and conventional straight-line access preparations were performed.

The experimental root canals were biomechanically prepared up to the CDC (cementum-dentin-canal) limit with a \#40 K-file (Dentsply/Maillefer, Ballaigues, Switzerland) and irrigated with different irrigating solutions: $2.5 \%$ sodium hypochlorite $(\mathrm{NaOCl})$ (Natu Pharmas, Goiânia, GO, Brazil); 2\% chlorhexidine (CHX) (Endogel, Endosupport, Itapetininga, SP, Brazil); vinegar (Toscano ${ }^{\circledR}$, apple vinegar, São Paulo, SP, Brazil). Three milliliters of each irrigating solution were used after each file and while instrumenting the root canals. An overinstrumentation was then performed with K-files to enlarge the main canal foramen to a \#30 instrument. The root canals were assigned to 4 groups, according to the irrigating solution and intracanal medicament used: 1) $2.5 \% \mathrm{NaOCl}+\mathrm{CHP}$; 2) $\mathrm{CHX}+\mathrm{CHP}$; 3) vinegar + CHP; 4) vinegar + vinegar. Root canals in groups 1 to 3 were dried with sterile paper points, completely filled with CHP (prepared with calcium hydroxide powder plus saline and introduced into the canal with a lentulo spiral drill) and the coronal openings were closed with a layer of Cimpat ${ }^{\circledR}$ (Septodont, France) and IRM $^{\circledR}$ (Intermediate Restorative Material; Dentsply Ind. Com. Ltda., Petrópolis, RJ, Brazil). In group 4, both the irrigating solution and intracanal medicament were vinegar, which was renewed every 7 days. 


\section{Evaluation of Antimicrobial Action}

After 21 days, the intracanal medicaments were removed from the teeth using saline and mechanical stirring with K-files. Subsequently, root canals were dried and filled with sterile saline. Samples were collected using aseptic techniques. The teeth were cleansed, isolated with a rubber dam and decontaminated (including the pulp chamber and the surrounding field) with $2.5 \%$ sodium hypochlorite. This solution was inactivated with sterile 5\% sodium thiosulfate. A \#15 $\mathrm{K}$-file was introduced to the CDC level and mechanical stirring was done. Afterwards, root canals were filled with sterile saline and two sterile paper points (Tanari, Tanariman Indústria, Ltda., Manacaru, AM, Brazil) were sequentially introduced to the CDC level. Each paper point was kept in position for $1 \mathrm{~min}$, and individually transported and immersed in $7 \mathrm{~mL}$ of Letheen broth (LB; Difco Laboratories, Detroit, MI, USA), a medium containing neutralizers and recommended for inhibition tests, followed by incubation at $37^{\circ} \mathrm{C}$ for $48 \mathrm{~h}$.

Microbial growth was evaluated by two methods, turbidity of the culture medium and subculture on a specific nutrient broth, because the tested medications caused changes in the culture medium. After assessing the LB changes, an inoculum of $0.1 \mathrm{~mL}$ obtained from the medium was transferred to $7 \mathrm{~mL}$ of brain heart infusion (BHI; Difco Laboratories, Detroit, MI, USA) and subsequently incubated at $37^{\circ} \mathrm{C}$ for $48 \mathrm{~h}$. Microbial growth was checked by turbidity of the culture medium and in some cases by Gram stain. All assays were carried out in duplicate under aseptic techniques.

Two control groups were used. A positive control was used to assess the viability of endodontic microorganisms during the experimental period. This group consisted of 8 teeth that were kept opened and

Table 1. Antimicrobial potential of the intracanal medicaments after 21 days in infected root canals of dogs' teeth.

\begin{tabular}{lcccccc}
\hline $\begin{array}{l}\text { Microbial } \\
\text { Growth }\end{array}$ & $\begin{array}{c}2.5 \% \mathrm{NaOCl} \\
+\mathrm{CHP}\end{array}$ & $\begin{array}{c}2 \% \mathrm{CHX} \\
+\mathrm{CHP}\end{array}$ & $\begin{array}{c}\text { Vinegar } \\
+\mathrm{CHP}\end{array}$ & $\begin{array}{c}\text { Vinegar } \\
+ \text { Vinegar }\end{array}$ & $\begin{array}{c}\text { Positive } \\
\text { Control }\end{array}$ & $\begin{array}{c}\text { Negative } \\
\text { Control }\end{array}$ \\
\hline $\begin{array}{l}\text { Presence } \\
\text { Absence }\end{array}$ & $30 \%$ & $30 \%$ & $40 \%$ & $60 \%$ & $100 \%$ & - \\
\hline
\end{tabular}

$\mathrm{CHP}=$ calcium hydroxide paste. $\mathrm{CHX}=$ chlorhexidine. microbial growth was analyzed by turbidity of the LB with incubation at $37^{\circ} \mathrm{C}$ for $48 \mathrm{~h}$. The microbial growth was then analyzed in $\mathrm{BHI}$ at the same incubation conditions. A negative control was used to assess the sterility of the culture medium. This group consisted of 8 samples with $7 \mathrm{~mL}$ of LB and then analyzed in BHI, under the same incubation conditions as that of the positive control group.

\section{RESULTS}

The results revealed that, within 21 days, all experimental groups had microbial growth in different percentages, despite the use of irrigating solutions and intracanal medicaments (Table 1). In the positive control group, the microorganisms were viable during the experimental period. The negative control group showed that the culture medium was sterile.

\section{DISCUSSION}

This study assessed the presence of microorganisms after biomechanical preparation and the use of different irrigating solutions and intracanal dressings over 21 days. However, it is important to adjust the study model, considering the same time to induce periapical lesion (6 months) and the biological conditions of the experimental model (dogs' teeth). Another important factor to be analyzed is the endodontic microbiota present, because the root canals were kept open and exposed to the oral environment for 6 months to induce periapical lesion.

The success of endodontic treatment is directly influenced by the control of microorganisms in infected root canals. It is therefore important to consider the type of infection occurring. The primary root canal infection is associated with endodontic microbiota generally composed of Gram-negative anaerobic bacteria. In root-filled teeth, the microorganisms can persist and maintain the apical periodontitis. Microorganisms present in secondary root canal infection are those that were resistant to the first treatment or penetrated after the root canal filling and coronal sealing.

Sundqvist et al. (15) de- 
termined what microbial flora was present in teeth after failed root canal therapy and established the outcomes of conservative re-treatment. The microbial flora was mainly composed of single species mostly of Grampositive organisms. The most commonly recovered isolates were bacteria of the species E. faecalis. The overall success rate of re-treatment was $74 \%$. The microbial flora in canals after failed endodontic therapy differed markedly from the flora found in untreated teeth. The infection at the time of root filling and the size of the periapical lesion were factors that had a negative influence on the prognosis. Three of four endodontic failures were successfully managed by retreatment. Sundqvist and Figdor (16) in a discussion on the life of endodontic pathogens concluded that root canal infection is not a random event. The type and the combination of the microbial flora developed in response to the surrounding environment. Factors that influence whether species shall die or survive are the particular ecological niche, nutrition, anaerobiosis, $\mathrm{pH}$ and competition with other microorganisms.

Different intracanal medicaments that control endodontic infections were used in the present study, each one with a specific antimicrobial mechanism of action. Group $1(\mathrm{NaOCl})$ and group 2 (CHX) had similar results $(70 \%$ of microorganisms present were eliminated). Little difference was observed in group 3 (vinegar + CHP), which had an absence of $60 \%$ of microorganisms after 21 days with CHP. It is important to mention the positive influence of CHP on microbial control.

Distilled white vinegar and wine vinegar are composed mainly of acetic acid $\left(\mathrm{C}_{2} \mathrm{H}_{4} \mathrm{O}_{2}\right)$, while apple vinegar is composed mainly of malic acid $\left(\mathrm{C}_{4} \mathrm{H}_{6} \mathrm{O}_{5}\right)$.

Vinegar has been indicated for centuries due to its medicinal properties. Acetic acid and vinegar have been used to treat infections in different health areas (12-14). The percentage of acetic acid in white distilled vinegar is higher than in the others. The malic acid from apple vinegar is the important element conferring its therapeutic properties. Apple vinegar has a wide range of minerals (potassium, phosphorus, chlorine, sodium, magnesium, calcium, sulfur, iron, fluorine and silicon). Other elements found in apple vinegar, such as pectin, beta-carotene, enzymes and amino acids, are able to attack the free radicals that interfere with the human body's immunity. Malic acid may boost the immune system with power supply within the cells, because it is one of the acids in the Krebs cycle (13).

On account of these advantages, apple vinegar was included in one experimental group of this study. Further research should investigate other variables, such as histopathologic evaluations following the use of different antimicrobial agents in teeth with apical periodontitis.

The antimicrobial agents most commonly used in endodontic therapy are $\mathrm{NaOCl}$ and CHP. In this study, the results of the CHX group were similar to those of the $\mathrm{NaOCl}$ group. Although $\mathrm{CHX}$ does have an antibacterial effect, its tissue dissolution ability is not good. EDTA, $\mathrm{NaOCl}, \mathrm{CHX}, \mathrm{CHX}$ chloride and ethanol have been shown to have little or no detoxifying ability for endotoxin - lipid A (17). On the other hand, calcium hydroxide has been shown to mediate degradation of bacterial lipopolysaccharide (18). E. faecalis, which are important bacteria in secondary infection, has been shown to be resistant to calcium hydroxide at $\mathrm{pH} 11.1$ but not pH 11.5 (19). It is necessary, whenever possible, to give enough time for the CHP to manifest its potential action against the microorganisms present in endodontic infections. The maintenance of a high concentration of hydroxyl ions can change the enzymatic activity and promote the microbial inactivation (8).

The results of this study, using the described methodology, are in accordance with the findings of other research (2,5-7,20). Kvist et al. (20) analyzed the antimicrobial efficacy of endodontic procedures performed in one session (including a 10-min intra-session dressing with $5 \%$ iodine-potassium-iodide) compared to a two-visit treatment (including an inter-session dressing with CHP). The initial sampling demonstrated the presence of microorganisms in $98 \%$ of the teeth. Postinstrumentation sampling showed reduction of cultivable microbiota. Antibacterial dressing further reduced the number of teeth with surviving microbes. In the postmedication samples, residual microorganisms were recovered in $29 \%$ of the one-visit treated teeth and in $36 \%$ of the two-visit treated teeth.

The lapse of time required by calcium hydroxide to express microbial inactivation is determined by several factors, i.e., quickness in dissociation and diffusion of hydroxyl ions, higher or lower dentinal permeability and buffering capacity of dentin. Further studies are necessary to determine new guidelines for the clinical protocol in the treatment of teeth with endodontic infections. It must not be forgotten that the primordial factor 
contributing significantly to either the healing process or the maintenance of an infection is the host response. Research currently indicates the need for an intracanal medication as an adjuvant in microbial control and tissue healing process. The biological characteristics of calcium hydroxide, represented by its tissue healing and antimicrobial potential, make this material the best therapeutic choice as an intracanal dressing.

Based on the results of this study, we conclude that all tested materials had antimicrobial potential. However, the positive role of calcium hydroxide paste on the healing process must not be forgotten, as research has shown its influence on the control of microorganisms.

\section{RESUMO}

Estudou-se a influência de diferentes irrigantes no potencial antimicrobiano da pasta de hidróxido de cálcio em dentes de cães com periodontite apical. 48 pré-molares de cães adultos tiveram suas câmaras coronárias abertas e expostas à cavidade bucal por 6 meses. Os canais radiculares foram preparados, irrigados e medicados com diferentes substâncias, de acordo com os seguintes grupos: 1) $2,5 \% \mathrm{NaOCl}+\mathrm{CHP}$; 2) $2 \% \mathrm{CHX}+\mathrm{CHP}$; 3 ) vinagre + CHP; 4) vinagre + vinagre. No grupo 4 , a solução irrigante e a medicação intracanal utilizada foi o vinagre. Neste grupo, a cada 7 dias, a solução era renovada. Cada amostra foi coletada, mantendo-se o cone de papel esterilizado em posição por $1 \mathrm{~min}$, e a seguir transportado e imerso em $7 \mathrm{~mL}$ de Letheen broth, seguido de incubação a $37^{\circ} \mathrm{C}$ por $48 \mathrm{~h}$. O crescimento microbiano foi analisado por dois métodos, turbidade do meio de cultura e subcultura em meio nutritivo específico (brain heart infusion). Os resultados mostraram que em todos os grupos experimentais houve crescimento microbiano após 21 dias, em diferentes percentagens: grupo $1-30 \%$; grupo $2-30 \%$; grupo $3-40 \%$; grupo $4-60 \%$. Todos os materiais testados apresentaram potencial antimicrobiano. Entretanto, o processo de cura favorecido pela pasta de hidróxido de cálcio não pode ser esquecido, uma vez que muitos estudos já demonstraram sua ação antimicrobiana.

\section{REFERENCES}

1. Holland R, Ingle JI, Valle GF, Taintor JF. Influence of bony resorption on endodontic treatment. Oral Surg Oral Med Oral Pathol 1983;55:191-203.

2. Byström A, Claesson R, Sundqvist G. The antibacterial effect of camphorated paramonochlorophenol, camphorated phenol and calcium hydroxide in the treatment of infected root canals. Endod
Dent Traumatol 1985;1:170-175.

3. Katebzadeh N, Hupp J, Trope M. Histological periapical repair after obturation of infected root canals in dogs. J Endod 1999;25:364-368.

4. Trope M, Delano O, Ørstavik D. Endodontic treatment of teeth with apical periodontitis: single vs. multivisit treatment. J Endod 1999;25:345-350.

5. Holland R, Otoboni-Filho JA, Souza V, Nery MJ, Bernabé PFE, Dezan-Jr E. A comparison of one versus two appointment endodontic therapy in dogs' teeth with apical periodontitis. J Endod 2003;29:121-125.

6. Holland R, Otoboni-Filho JA, Souza V, Nery MJ, Bernabé PFE, Dezan-Jr E. Tratamiento endodontico en una o en dos visitas. Estudio histológico en dientes de perros con lesión periapical. Endodoncia 2003;21:20-27.

7. Estrela C, Estrela CRA, Pécora JD. A study of the time necessary for calcium hydroxide to eliminate microorganisms in infected canals. J Appl Oral Sci 2003;12:133-137.

8. Estrela C, Holland R. Calcium hydroxide: study based on scientific evidences. J Appl Oral Sci 2003;11:269-282.

9. Holland R, Soares IJ, Soares IM. Influence of irrigation and intracanal dressing on the healing process of dog's teeth with apical periodontitis. Endod Dent Traumatol 1992;8:223-229.

10. Jeansonne MJ, White RR. A comparison of $2 \%$ chlorhexidine gluconate and $5.25 \%$ sodium hypochlorite as antimicrobial endodontic irrigant. J Endod 1994;20:276-278.

11. Estrela C, Ribeiro RG, Estrela CRA, Pécora JD, Sousa-Neto MD. Antimicrobial effect of $2 \%$ sodium hypochlorite and $2 \%$ chlorhexidine tested by different methods. Braz Dent J 2003; 14:58-62.

12. Thacker E. O Vinagre. São Paulo: Pacific Post Com Ldta. 2000.

13. Valnet J. Aromathérapie. Paris: Librairie Maloine Éditeur. 1973.

14. Phillips I, Lobo AZ, Fernandes R, Gundara NS. Acetic acid in the treatment of superficial wounds infected by Pseudomonas aeruginosa. Lancet 1968;6:11-12.

15. Sundqvist G, Figdor D, Persson S, Sjögren U. Microbiologic analysis of teeth with failed endodontic treatment and the outcome of conservative re-treatment. Oral Surg Oral Med Oral Pathol Oral Radiol Endod 1998;85:86-93.

16. Sundqvist G, Figdor D. Life as an endodontic pathogen. Ecological differences between the untreated and the root-filled root canals. Endodon Topics 2003;6:3-28.

17. Buck RA, Cai J, Eleazer PD, Staat RH, Hurst HE. Detoxification of endotoxin by endodontic irrigants and calcium hydroxide. J Endod 2000;27:325-327.

18. Safavi KE, Nichols FC. Alteration of biological properties of bacterial lipopolysaccharide by calcium hydroxide treatment. J Endod 1994;20:127-129.

19. Evans M, Davies JK, Sundqvist G, Fidgor D. Mechanism involved in the resistance of Enterococcus faecalis to calcium hydroxide. Int Endod J 2002;35:221-228.

20. Kvist T, Molander A, Dahlén G, Reit C. Microbiological evaluation of one- and two-visit endodontic treatment of teeth with apical periodontitis: a randomized, clinical trial. J Endod 2004;30:572-576. 